Annuaire suisse de politique de développement

4 | 1984

Annuaire Suisse - Tiers Monde 1984

\title{
Les perspectives pour le développement de la coopération suisse
}

Richard Gerster

\section{(2) OpenEdition}

1 Journals

Édition électronique

URL : http://journals.openedition.org/aspd/1180

DOI : $10.4000 /$ aspd. 1180

ISSN : 1663-9669

Éditeur

Institut de hautes études internationales et du développement

\section{Édition imprimée}

Date de publication : 1 janvier 1984

Pagination : 147-153

ISSN : 1660-5934

\section{Référence électronique}

Richard Gerster, "Les perspectives pour le développement de la coopération suisse », Annuaire suisse de politique de développement [En ligne], 4 | 1984, mis en ligne le 28 mai 2013, consulté le 08 septembre 2020. URL : http://journals.openedition.org/aspd/1180 ; DOI : https://doi.org/10.4000/aspd.1180

Ce document a été généré automatiquement le 8 septembre 2020.

(C) The Graduate Institute | Geneva 


\title{
Les perspectives pour le développement de la coopération
} suisse

\author{
Richard Gerster
}

\section{NOTE DE L'ÉDITEUR}

Lire l'article original en allemand dans Schweizerisches Jahrbuch für Entwicklungspolitik:

«Perspektiven zum Ausbau der Schweizerischen Entwicklungszusammenarbeit », http://sjep.revues.org/992.

\section{AUTEUR}

RICHARD GERSTER

Coordinateur de la communauté de travail des organismes d'entraide Swissaid / Action de Carême / Pain pour le prochain / Helvetas. 